\title{
Nursing Approach Based on Roy Adaptation Model in a Patient Undergoing Breast Conserving Surgery for Breast Cancer
}

Figen Erol Ursavaş ${ }^{1}$, Özgül Karayurt² ${ }^{2}$ Özge İşeri ${ }^{3}$

${ }^{1}$ Department of Nursing, Çankırı Karatekin University School of Health Service, Çankırı, Turkey

${ }^{2}$ Department of Nursing, Dokuz Eylül University Faculty of Nursing, İzmir, Turkey

${ }^{3}$ Department of Nursing, Gaziosmanpaşa University, Tokat School of Health Service, Tokat, Turkey

\begin{abstract}
The use of models in nursing provides nurses to focus on the role of nursing and its applications rather than medical practice. In addition, it helps patient care to be systematic, purposeful, controlled and effective. One of the commonly used models in nursing is Roy Adaptation Model. According to Roy adaptation model, the aim of nursing is to increase compliance and life expectancy. Roy Adaptation Model evaluates the patient in physiologic mode, self-concept mode, role function mode and interdependence mode aiming to provide holistic care. This article describes the use of Roy Adaptation Model in the care of a patient who has been diagnosed with breast cancer and had breast-conserving surgery. Patient data was evaluated in the four modes of Roy adaptation model (physiologic, self-concept, role function, and interdependence modes) and the nursing process was applied.
\end{abstract}

Key words: Breast cancer, nursing, Roy Adaptation Model

\section{Introduction}

Breast cancer is a malignant tumor that originates from breast cells. Breast cancer is the most common type of cancer in American women, except skin cancer. According to the most recent data from the United States, 232.340 (29\%) new cases of breast cancer was diagnosed in 2013, and it is estimated that approximately 39,620 of those will die due to breast cancer (1). According to 2011 data from the Ministry of Health in Turkey, breast cancer ranks top among women with an incidence of 45.1 per hundred thousand (2).

Nurses' providing holistic care in the care of women with breast cancer is very important. Nurses can achieve in providing holistic care only with the use of nursing models. By using these models, nursing activities shift away from being service-centered to serving in a patient-focused manner (3). In addition, basic concepts and relationships between concepts are determined, problems are identified and solutions can be developed (4). In this way, nurses focus on the role of nursing and its applications rather than medical practice (5). Models not only ensure purposeful, systematic, controlled and effective patient care but also create a common language. In addition, by helping nurses to organize daily care it creates the opportunity to give high quality care with less labor (6). Despite the increase in the interest in models, use of these models in nursing practice is not common. The most important reasons for this is not emphasizing models as part of basic nursing education and most models having a complex structure including abstract concepts. For this reason, understanding and applying models by clinical nurses can be time-consuming (7). One of the widely used models in nursing is Roy Adaptation Model (RAM). RAM has been contributing to nursing practice, research, education and management and has been providing model-based information for the last 35 years (8).

In our country, the use of models in nursing practice and research has gained importance in the recent years $(6,7,9-12)$. Nurses' providing care to patients by using a model will provide holistic care. This article aims to explain application of RAM in care of a patient who has been diagnosed with breast cancer and had undergone breast-conserving surgery. Determination of nursing diagnoses and applications according to RAM forms the basis of this article.

\section{Conceptual Framework: Roy Adaptation Model}

The Roy Adaptation Model is a model widely used in the identification of conceptual foundation of nursing. The development of the model began in the late 1960s (3). Nurses from the United States and countries all around the world aim to emphasize and explain RAM as well as expanding its concepts (3). Roy defined nursing as a scientific and humanistic profession, and emphasized the importance of their specialized knowledge in contributing health needs and well-being of the community $(3,13)$. According to RAM, the purpose of nursing is to increase compliance and life expectancy. 
Table 1. The classification of the individual's positive physiologic mode adaptation indicators

\section{Physiologic mode}

1- Oxygenation

- Balanced ventilation period

- Balanced gas exchange style

- Sufficient gas exchange

- Sufficient compensation period

2- Nutrition

- Balanced digestion period

- Sufficient nutrition style for body requirements

- Supplying metabolic and nutritional requirements with altered nutrition style

3- Elimination

- Sufficient bowel evacuation period

- Balanced bowel evacuation style

- Sufficient urination period

- Balanced urinary elimination style

- Efficient coping methods in case of altered evacuation style

4- Activity and rest

- Sufficient activity period

- Sufficient empowerment of balancing movements during immobility

- Sufficient activity and resting style

- Sufficient sleep period

- Environmental changes effecting sleep disturbances

5- Protection

- Intact skin

- Sufficient healing period

- Sufficient secondary protection against changes in immune status and skin integrity

- Sufficient immune period

- Sufficient heat regulation

6- Senses

- Sufficient emotion period

- Efficient integration of emotional data input

- Balance of perceptive input and evaluation

- Efficient coping methods in case of altered sense

7- Fluid-electrolyte and acid-base balance

- Sufficient period in fluid balance

- Balanced electrolyte levels of body fluids

- Balanced acid-base status

- Efficient organization of chemical buffering

8- Neurologic Function

- Efficient response in sense, perception, coding, concept formation, memory, language, planning and motor response

- Integration of thought and sense processes

- Development of flexibility and functional effectiveness during neurologic system aging and alteration

9- Endocrine Function

- Efficient hormonal regulation during body and metabolic processes

- Efficient hormonal regulation in reproductive development

- Negative feedback closed circuit balance in hormonal regulation

- Balanced hormone cycle rhythm

- Efficient stress management methods

Roy C. The roy adaptation model. $3^{\text {rd }}$. ed. Upper Saddle River New Jersey, Pearson Education, 2009(3) 
The metaparadigm concepts of Roy Adaptation Model are person, environment, health and nursing (4). The Roy Adaptation Model sees the person as a biopsychosocial being in continuous interaction with a changing environment. The environment includes focal, contextual and residual stimuli. A focal stimulus is the confrontation with one's internal and external environment. The individual immediately resists these internal and external stimuli. Nurses aim to manage the focal stimulus first, and then the contextual stimuli $(3,4,14)$. The contextual stimuli are those other stimuli that contribute to the focal stimuli and affect the current situation (3). The residual stimuli are closed factors affecting the current situation. These are beliefs, behaviors and personal experiences. They originate from the past and affect the response to treatment $(3,14)$. Health is an anticipated dimension of human life and represents a health-disease continuum (3). Roy defined health as the process of being and becoming an integrated and complete person (14). Roy's model of nursing defined nursing as a science, and the adaptation of this scientific knowledge into the practice of nursing (14). According to RAM, the purpose of nursing is to ensure adaptation. Increasing adaptation during health and disease improves the interaction between the environment and human systems and thus improves health. Therefore, it contributes to health, quality of life and end of life care (3). RAM also expressed specific activities distinguishing nursing from other disciplines as the nursing process. Roy proposed a problem solving approach in this process and explained this approach in five stages. These are "1. Assessment of behavior and stimuli, 2. Diagnosis, 3. Goal setting, 4. Planning, 5. Intervention and evaluation” (14).

The Roy Adaptation Model defined the innate and acquired coping processes as two sub-systems (3). The regulator subsystem consists of neuro-chemical and endocrine response. Internal and external stimuli include social, physical and psychological factors. The cognator subsystem is related more to attention, memory, learning, problem solving, decision-making, excitement, and defense status $(3,13)$.

The four modes of adaptation defined in Roy Adaptation Model are physiologic, self-concept, role function and interdependence modes. Nurses help to meet the needs of individuals in these modes of adaptation $(3,13)$.

\section{The Physiologic Mode}

The physiologic mode is associated with the physical answers of the person, given to stimuli from the environment (14). It includes the physical and chemical processes within an individual's life and activities. Physiologic mode requirements are based on physiologic integrity. This mode consists of nine basic physiologic requirements: 1) Oxygenation, 2) nutrition, 3) Elimination, 4) activity and rest, 5) Protection, 6) Senses, 7) Fluid-electrolyte and acid-base balance, 8) Neurologic function and 9) Endocrine function. Physiological integrity is an essential requirement for physiologic mode (3). Table 1 represents the classification of the individual's positive physiologic mode adaptation indicators according to RAM.

\section{The Self Concept Mode}

The self-concept mode is defined as the individual's mixture of beliefs and feelings about himself or others at a certain time. The self-concept mode consists of the physical self and personal identity. Physical self contains body image and body sense. Personal identity is formed by their thoughts, moral-ethics and spirituality (3). Table 2 represents the individual's positive self-concept mode adaptation indicators accord-
Table 2. The classification of the individual's positive self-concept mode adaptation indicators

\section{Self-concept mode}

- Positive body image

- Effective sexual function

- Spiritual integrity in physical growth

- Sufficient compensation for body changes

- Sufficient coping methods in loss

- Efficient period in end-of-life

- Sufficient integration of own ideas

- Balanced consistency

- Efficient period in moral-ethic and spiritual development

- Functional self respect

- Efficient coping methods in threat against oneself

Roy C. The roy adaptation model. 3 rd. ed. Upper Saddle River New Jersey, Pearson Education, 2009(3)

Table 3. The classification of the individual's positive role function mode adaptation indicators

\section{Role function mode}

- Identification of roles

- Efficient role changing period

- Combination of non-verbal and explanatory role movements

- Combination of primary, secondary and tertiary roles

- Efficient example in fulfilling roles

- Efficient coping methods in role changing

- Responsibility to fulfill roles

- Combining efficient roles

- Balanced role sufficiency

Roy C. The roy adaptation model. 3 rd. ed. Upper Saddle River New Jersey, Pearson Education, 2009(3)

Table 4. The classification of the individual's positive interdependence mode adaptation indicators

\section{Role function mode}

- Sufficient love

- Balanced love, respect, giving and taking value

- Efficient dependent and independent examples

- Efficient coping methods in case of loneliness and separation

- Sufficient development for learning and maturation in relationships

- Sufficient communication and relation

- Providing developmental talent in formation of attention and care

- Trust in relationships

- Sufficiency of support systems and close individuals in providing development

Roy C. The roy adaptation model. 3 rd. ed. Upper Saddle River New Jersey, Pearson Education, 2009(3) 
The Role Function Mode

The role function mode covers the individual's role in society for social integrity. The roles described herein are divided in three: 1. primary roles; the role of gender (female, male), 2. secondary roles; different roles (mother, father, teacher, etc.), and 3. tertiary roles (president of an association, etc.) (3). The basic requirement for role function mode is defined as social integrity (14). Role function mode applies to both individuals and groups at all levels. It includes designated and informal

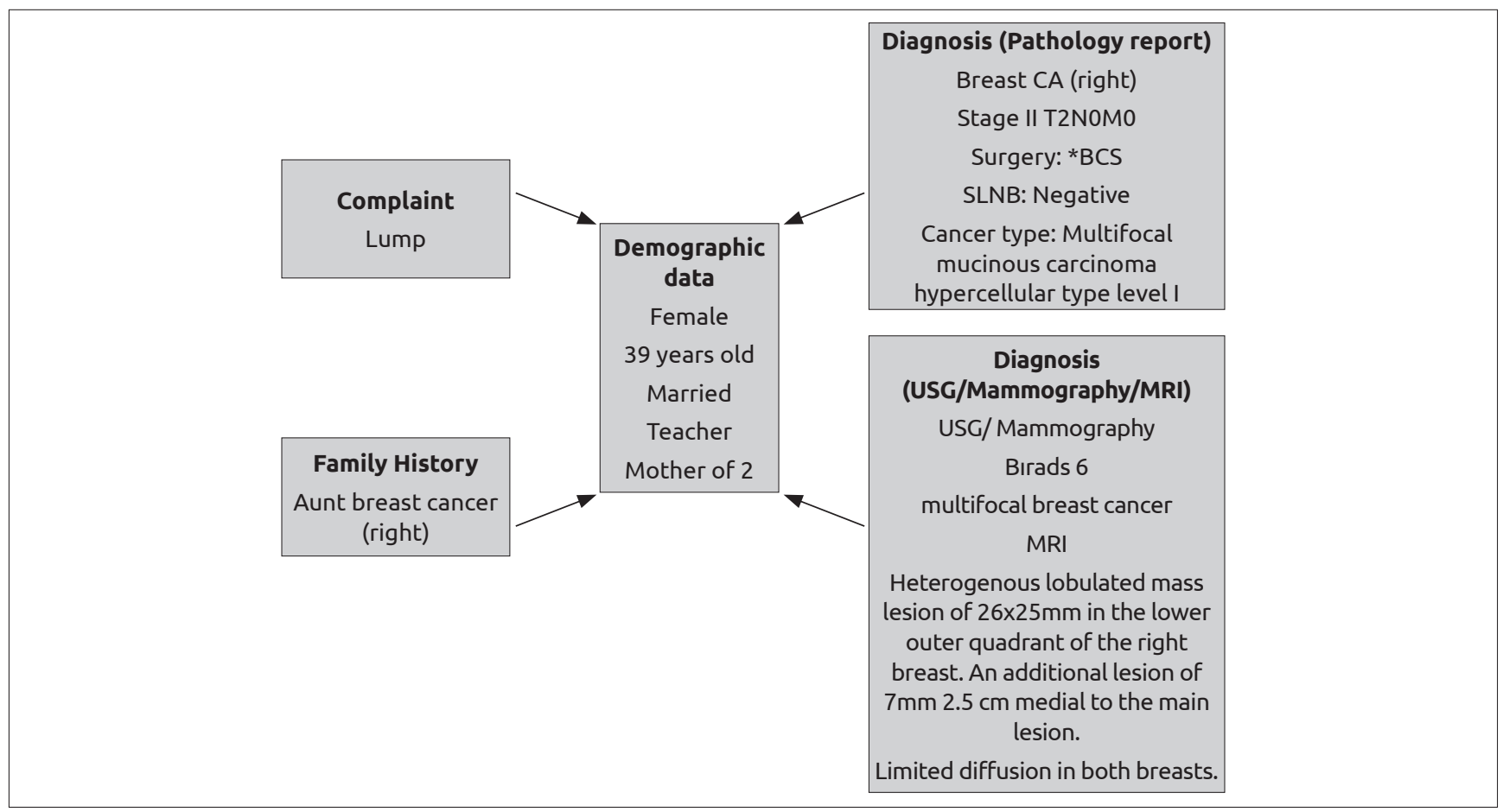

Figure 1. Patient demographic and clinical data

BCS: Breast conserving surgery; USG: Ultrasonography; MRI: Magnetic Resonance Imaging

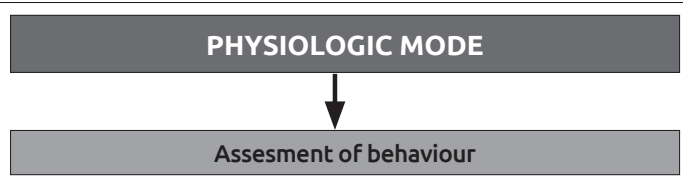

Patient Claim: It took me one month before I can completely use my arm after surgery. I was not able to use that arm. My doctor told me that I could use that arm in anyway but when I moved it I felt burning. Therefore I limited my activities.



Figure 2. Patient data related to physiologic mode of RAM and nursing interventions 


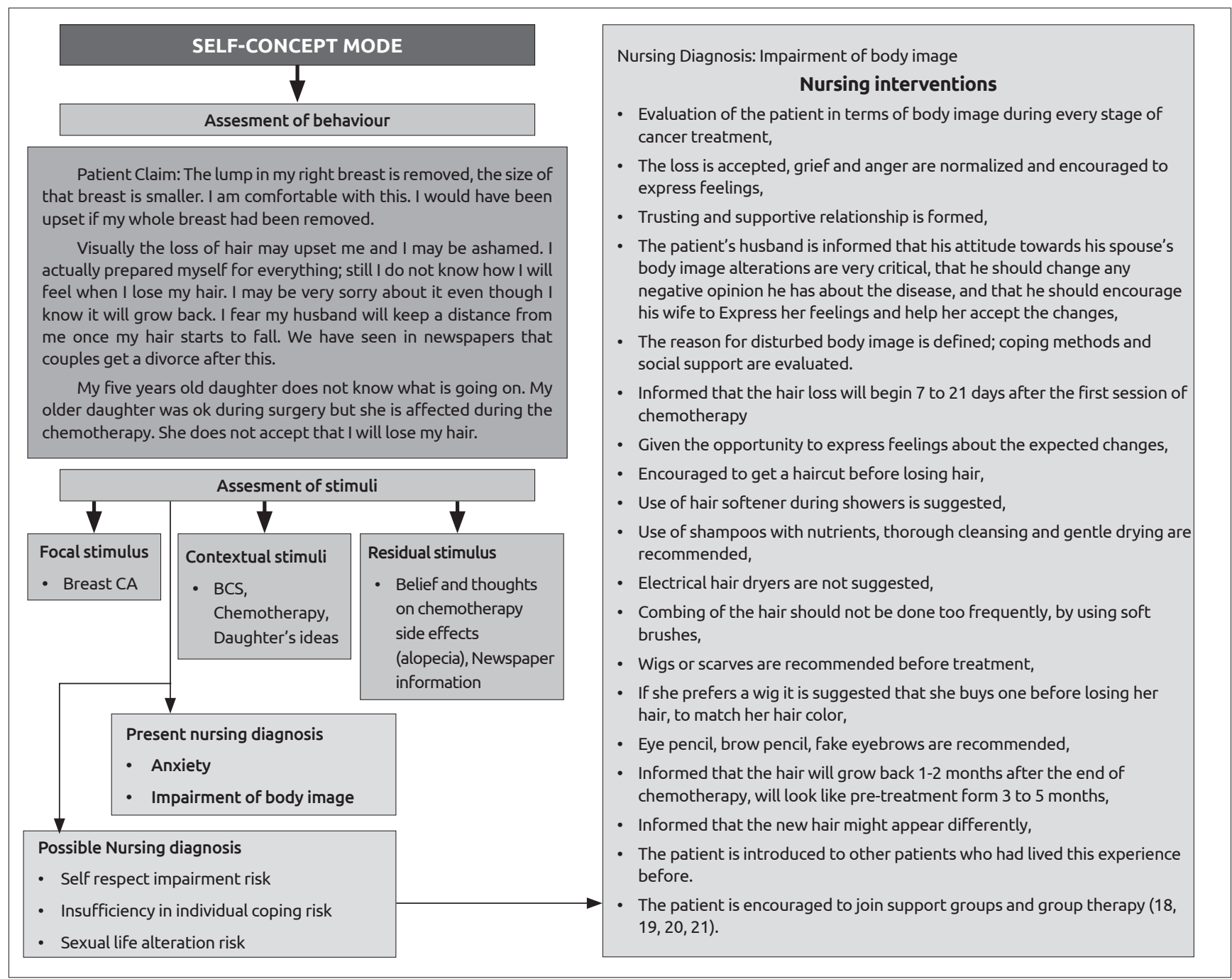

Figure 3. Patient data related to self-concept mode of RAM and nursing interventions

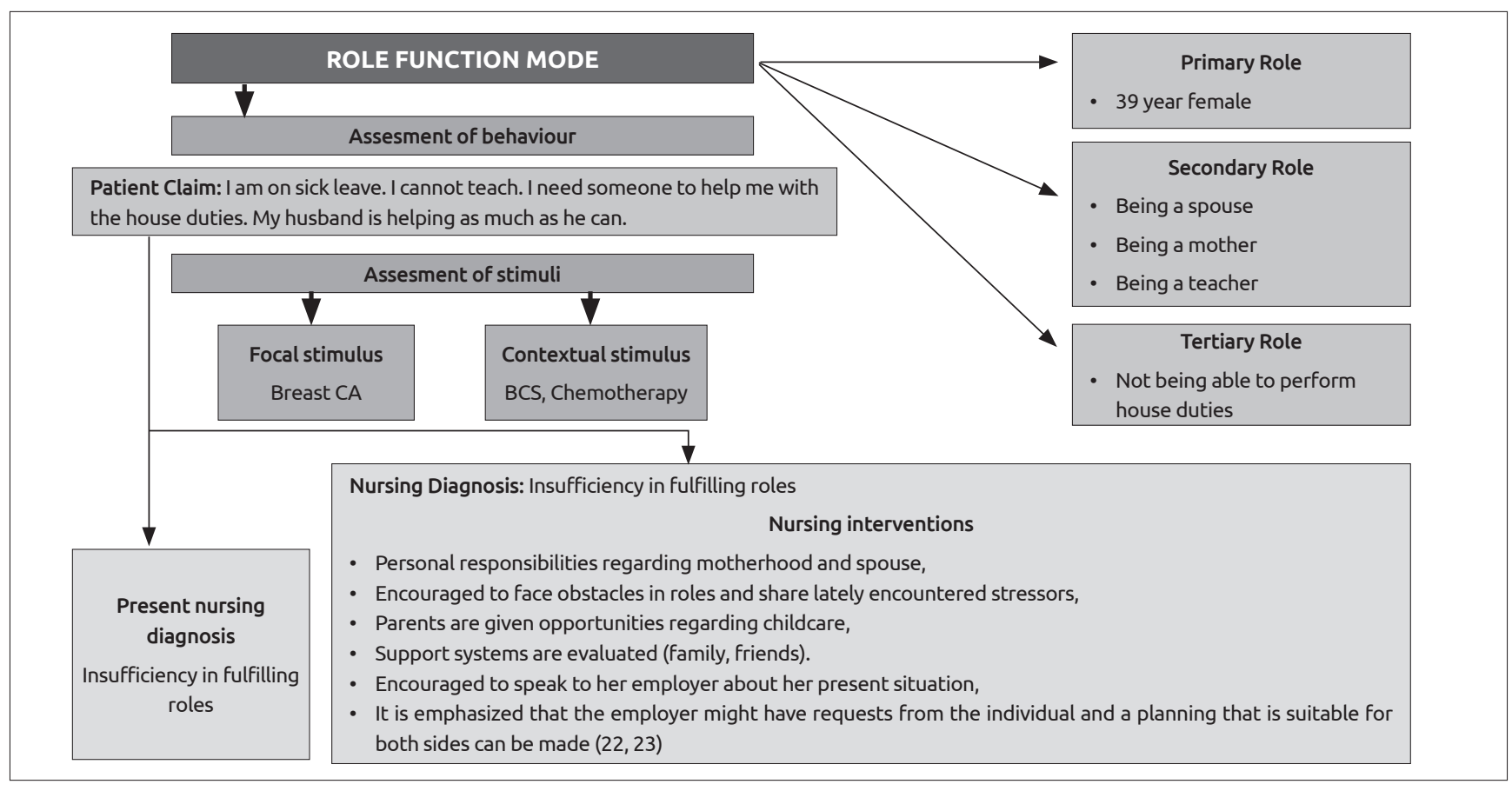




\section{INTERDEPENDENCE MODE}

Assesment of behaviour

Patient Claim: My husband, family, and friends are sorry for me. They have been great support, spiritually. Their care made me feel better. I spent more time with my friends since my family lives abroad. I spoke to my family over the phone. I carried on my daily life.

...My husband is trying to take care of our children more. He was not helping me this much before.

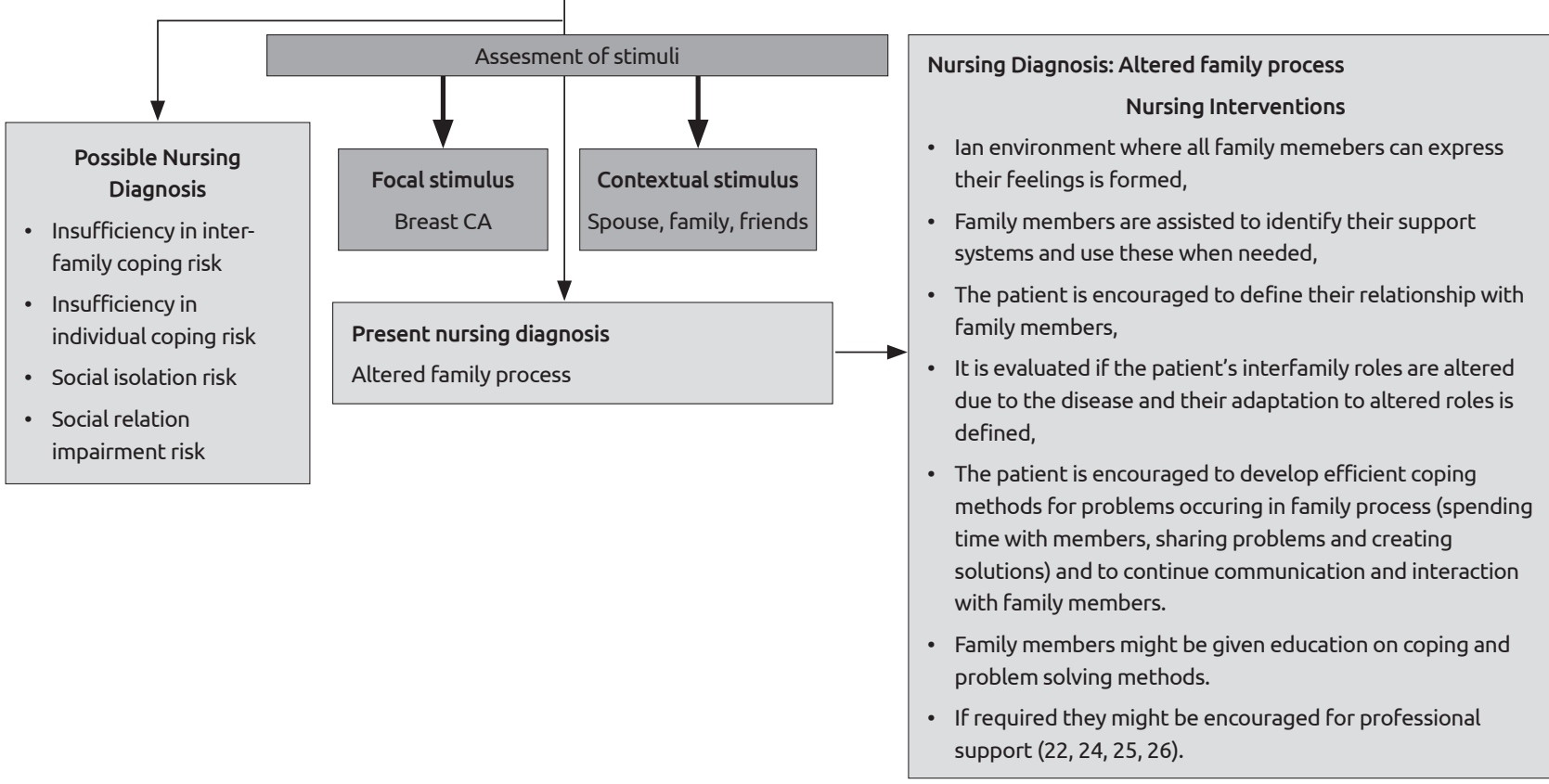

Figure 5. Patient data related to interdependence mode of RAM and nursing interventions

roles (15). Table 3 represents the individual's positive role function mode adaptation indicators according to RAM.

\section{The Interdependence Mode}

The behavior and mutual relations of individuals and groups are explained by interdependence in RAM. The interdependence mode includes relationships with others that are meaningful to the person, and support systems. For the individual, this mode focuses on interactions related to love, respect, giving and receiving value. The basic requirement of this area is the creation of a sense of confidence by relationship integrity and improvement of relationships $(3,13)$. Proficiency in relationships forms the basis of group requirements. The components of interdependence mode for groups are the situation, infrastructure and the capability of members. The external context includes economic, social, political and cultural factors, while the internal context includes the mission, aim, vision, value, belief and goals of the group. For each group, the infrastructure involves both official and unofficial processes, operations and system interactions. Their capability includes cognitive coping skills, knowledge, skill, behavior and responsibilities. The processes that underlie this area are competence in relationships, development and resource (15). Table 4 represents the individual's positive interdependence mode adaptation indicators according to RAM.

\section{Nursing approach based on Roy Adaptation Model in a patient undergoing breast conserving surgery}

The patient had undergone breast conserving surgery (BCS) 45 days ago and was interviewed in the first course of her chemotherapy treat- ment. A verbal informed consent was obtained from the patient before the interview. Patient demographic and clinical data are given in Figure 1. Patient data related to physiologic mode of RAM and nursing interventions are depicted in Figure 2. Patient data related to self-concept mode of RAM and nursing interventions are depicted in Figure 3. Patient data related to role function mode of RAM and nursing interventions are depicted in Figure 4. Patient data related to interdependence mode of RAM and nursing interventions are depicted in Figure 5.

In this article, nursing interventions including holistic care according to the Roy Adaptation Model were described, with a patient who had undergone breast conserving surgery. Being diagnosed with and undergoing treatment for cancer may lead to bio-psycho-social problems. It is expected that the development of interventions specific to the individual by nurses, will yield positive results in the adaptation of patients who are trying to cope with these problems. By this means, the patients will be adapted to their new life and their quality of life will improve. The utilization of theories will facilitate the situation and will provide a means for the nurses to focus on their profession of nursing, and develop a holistic care in biopsychosocial approach to the patients they are taking care of. For that reason, it is essential that the use of theories in nursing care, should be encouraged and their implementation into practice should be enhanced.

Conflict of Interest: No conflict of interest was declared by the authors. 
Peer-review: Externally peer-reviewed.

Informed Consent: Informed consent was taken from the patients.

Author Contributions: Concept - Ö.K.; Design - F.E.U., Ö.K., Ö.İ.; Supervision - Ö.K., Ö.İ.; Funding - F.E.U.; Materials - F.E.U.; Data Collection and/or Processing - F.E.U., Ö.İ.; Analysis and/or Interpretation - F.E.U., Ö.İ., Ö.K.; Literature Review - F.E.U., Ö.K.; Writer - F.E.U. Ö.K., Ö.İ.; Critical Review - Ö.K., Ö.İ.

Financial Disclosure: The authors declared that this study has received no financial support.

\section{References}

1. American Cancer Society. What are the key statistics about breast cancer. Erişim tarihi: 03/10/2013. http://www.cancer.org/cancer/breastcancer/ detailedguide/ breast-cancer-key-statistics.

2. Sağlık İstatistikleri Yıllığı 2012 http://sbu.saglik.gov.tr/Ekutuphane/kitaplar/istaturk2012.pdf Erişim tarihi: 03/05/2014.

3. Roy C. The Roy adaptation model. 3 edition. Upper Saddle River New Jersey, Pearson Education; 2009.

4. Fawcett J. Contemporary nursing knowledge analysis and evaluation of nursing models and theories. Second Edition. F.A. Davis Company, Philadelphia, 2005.

5. Gigliotti, E. The value of nursing models in practice. DEUHYO ED 2008; 1: 42-50.

6. İşbir GG, Mete S. Hemșirelik bakımında model kullanımına bir örnek: bulantı kusma sorunu olan bir gebenin roy uyum modeline göre incelenmesi. DEUHYO ED 2009; 2: 75-86.

7. Vicdan AK. Hemşirelik bakımında model kullanımına bir örnek: modifiye radikal mastektomi olmuş bir bayanın Roy'un adaptasyon modeline göre incelenmesi. Maltepe Üniversitesi Hemşirelik Bilim ve Sanatı Dergisi 2010; 2: 107- 118 .

8. Parker ME. Nursing theories and nursing practice. Second edition Philadelphia; 2005.

9. Şimşek AB, Dicle A. Primer beyin tümörlü hastaların roy uyum modeli'ne göre uyum durumlarının incelenmesi: niteliksel bir araştırma. Journal of Neurological Sciences 2013; 30: 88-107.

10. Ordin YS, Karayurt Ö, Wellard S. Investigation of adaptation after liver transplantation using Roy's adaptation model. Nurs Health Sci 2013; 15: 31-38. (PMID: 23094933) [CrossRef]
11. Özkaraman A, Özer S, Alpaslan GB. Romatoid artritli bir vakanın hemşirelik bakımında roy adaptasyon modelinin kullanımı. Gümüşhane Üniversitesi Sağlık Bilimleri Dergisi 2012 1: 138-152.

12. Figen PS, Mete $S$. Uyum modeli ve sosyal bilişsel öğrenme kuramının doğum öncesi eğitimde kullanımı. DEUHYO ED 2009; 1: 57-68.

13. Pektekin C. Sister callistra roy ve adaptasyon kuramı In: hemşirelik felsefesi kuramlar bakım modelleri ve politik yaklaşımlar. İstanbul Tıp kitapevi, 2013.

14. Velioğlu P. Hemşirelikte kavram ve kuramlar. İstanbul, 1999.

15. Roy C. Extending the Roy adaptation model to meet changing global needs. Nurs Sci Q 2011; 24: 345-351. (PMID:21975483) [CrossRef]

16. Smetzer, SC, Bare, BG, Hinkle JL, Cheever KH. Brunner Suddarth's Textbook of Medical Surgical Nursing 2010.

17. American Cancer Society. Exercises After Breast Surgery. Breast surgery can affect arm movement. Erişim Tarihi: 30/04/2013. http://www.cancer. org/cancer/breastcancer/moreinformation/exercises-after-breast-surgery

18. Yangın HB. Cilt değişiklikleri/alopesi In. Can G. Onkoloji hemşireliğinde kanıta dayalı bakım. İstanbul Konsensusu Nobel Tip Kitapevi, 2010.

19. Hastalar için kemoterapi rehberi. http://www.kanser.org/toplum/pdf/Kemoterapi_Rehberi.pdf Erişim tarihi: 03/10/2013.

20. Ünsar S, Fındık ÜY, Kurt S, Özcan H. Kanserli hastalarda evde bakım ve semptom kontrolü. Fırat Sağlık Hizmetleri Dergisi 2007; 2: 90-106.

21. Cancercare Understanding and managing. Chemotherapy side effects. Connect booklet series. Erişim Tarihi: 03/10/2013. http://media.cancercare.org/publications/original/24-ccc_chemo_side_effects. pdf? 1330707352

22. Erol Ö, Avşar F, Bedük T. Kanser hastasının yaşamı / rol ve ilişkiler. In: Can G. Onkoloji hemşireliğinde kanıta dayalı bakım. İstanbul Konsensusu Nobel Tip Kitapevi, 2010.

23. Erdemir F. Hemşirelik tanıları el kitabı 2. Baskı Nobel Tıp Kitabevleri, 2005.

24. Buzlu S, Daştan NB. Kanser Hastalarının Yaşamı/Başetme In.: Can G. Onkoloji hemşireliğinde kanıta dayalı bakım. İstanbul Konsensusu Nobel Tip Kitapevi, 2010.

25. Özcan A. Şizofrenik, paranoid (delüzyonel) ve diğer psikotik bozukluklar. In: Kum N. Psikiyatri hemşireliği el kitabı.Vehbi Koç Vakfi İstanbul, 2000.

26. Çam $\mathrm{O}, \mathrm{Gümüş} \mathrm{AB.} \mathrm{Meme} \mathrm{kanserli} \mathrm{kadınlar} \mathrm{için} \mathrm{duygusal} \mathrm{destek} \mathrm{odaklı}$ hemşirelik girişimleri. C.Ü. Hemşirelik Yüksekokulu Dergisi 2006; 10(3): 52-59. 